\title{
POPULATION ABUNDANCE AND SEX RATIO OF THE VIVIPAROUS FRESHWATER FISH POECILIOPSIS BAENSCHI (POECILIIDAE) THROUGHOUT ITS RANGE IN WESTERN MEXICO
}

\author{
J. Jaime Zúñiga-Vega ${ }^{1,3}$, Ana L. Hernández-Rosas ${ }^{1}$, Alejandro Molina-Moctezuma ${ }^{1}$, \\ Hibraim A. Pérez-Mendoza ${ }^{1}$, Fernanda R. Rodríguez-Reyes ${ }^{1}$, Yolotzin M. Bravo-Espinosa ${ }^{1}$, \\ and Héctor Espinosa-Pérez
}

\begin{abstract}
We estimated population abundance and sex ratio for a freshwater live-bearing fish species (Poeciliopsis baenschi) that inhabits fluvial systems in western Mexico. We conducted mark-recapture experiments in 6 distinct populations. We used both our catch data as well as estimates of capture probability to calculate the number of individuals per unit water volume for adult males, adult females, and juveniles. Overall, abundance varied among sites from 23.8 individuals $\cdot \mathrm{m}^{-3}$ to 363.2 individuals $\cdot \mathrm{m}^{-3}$. In most of our study sites, the estimated sex ratio was markedly biased toward females (up to 11 females per male). We discuss the potential causes and implications of the observed demographic features.

RESUMEN.-Estimamos abundancia poblacional y proporción sexual para una especie de pez vivíparo de agua dulce (Poeciliopsis baenschi) que habita sistemas fluviales en el occidente de México. Llevamos a cabo experimentos de marcaje y recaptura en seis poblaciones distintas. Utilizamos tanto nuestras capturas observadas así como estimaciones de probabilidad de captura para calcular el número de individuos por unidad de volumen de agua para machos adultos, hembras adultas y juveniles. En general, la abundancia varió entre sitios desde 23.8 individuos por $\mathrm{m}^{3}$ y hasta 363.2 individuos por $\mathrm{m}^{3}$. En la mayoría de nuestros sitios de estudio, la proporción sexual estimada estuvo marcadamente sesgada hacia las hembras (hasta 11 hembras por cada macho). Discutimos las causas potenciales y las implicaciones de los rasgos demográficos observados.
\end{abstract}

Population abundance and sex ratio are basic demographic parameters that still need description for a large number of animal species. In the Neotropics, studies estimating demographic parameters of freshwater fishes are notably scarce in comparison with those focused on Nearctic and Palearctic regions (e.g., Killgore et al. 2007, High et al. 2008, Young et al. 2010). As a consequence, little is known about the relative abundance, population characteristics (e.g., sex ratio), and persistence probabilities of these organisms in fluvial systems of the Neotropics (but see Arce-Uribe 2006, Ramos-Santiago et al. 2006, Canto-Maza and Vega-Cendejas 2007). The current rate of change in land use and water pollution in highly diverse neotropical ecosystems (Miguel 1991, Achard et al. 2002) also makes it imperative to know basic demographic traits of freshwater fish species. This demographic information can then be used to guide conservation or management plans (Caswell 2000, 2001, Williams et al. 2002).

Viviparous fishes of the family Poeciliidae are particularly interesting because most species are restricted to tropical freshwater environments and several have markedly narrow distributional ranges (Evans et al. 2011). The high level of endemism observed in many of these fishes makes them vulnerable to humancaused disturbance (Duncan and Lockwood 2001, Contreras-Balderas et al. 2003). Unfortunately, only a few widespread species have been demographically characterized (e.g., Brachyrhaphis rhabdophora, Gambusia affinis, Gambusia holbrooki, Heterandria formosa, and Poecilia reticulata; Jordan et al. 1998, Bronikowski et al. 2002, Smith 2005, Richardson et al. 2006, Johnson and Zúñiga-Vega 2009, Johnson and Bagley 2011), and we know little about basic population traits such as abundance and sex ratio for poeciliids with restricted geographic

${ }^{1}$ Departamento de Ecología y Recursos Naturales, Facultad de Ciencias, Universidad Nacional Autónoma de México. Ciudad Universitaria 04510, Distrito Federal, México.
${ }^{2}$ Colección Ictiológica, Departamento de Zoología, Instituto de Biología, Universidad Nacional Autónoma de México. Ciudad Universitaria 04510, Distrito Federal, México.

32E-mail: jzuniga@ciencias.unam.mx 


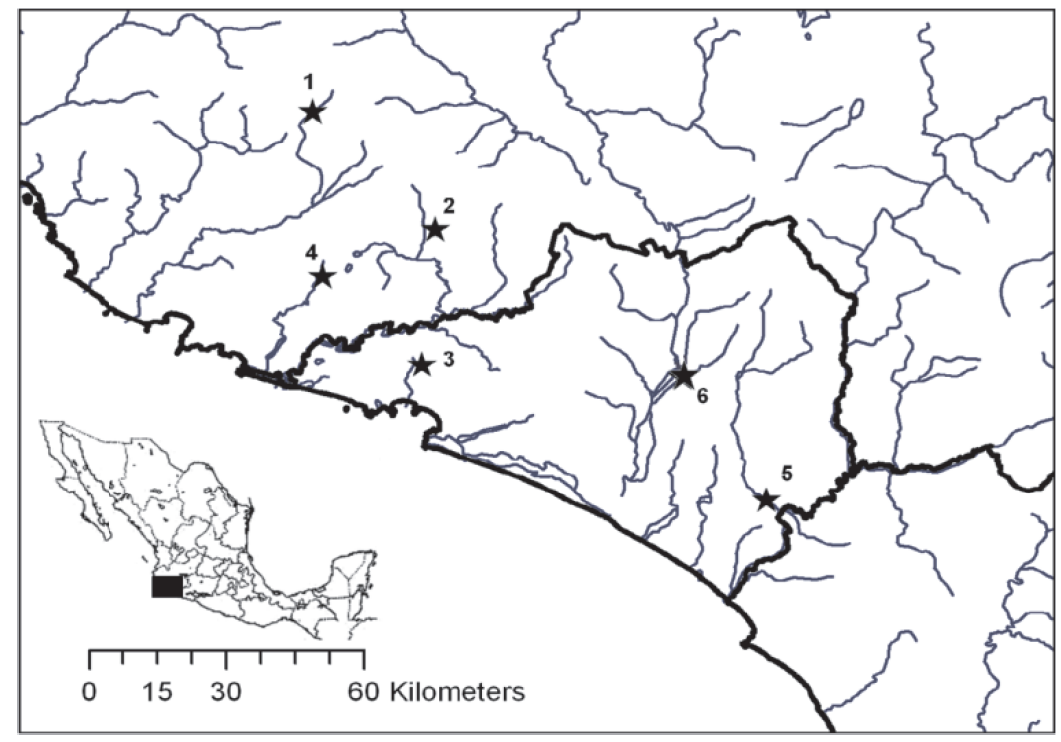

Fig. 1. Geographic location of the 6 studied populations of Poeciliopsis baenschi. Numbers indicate study sites as per Table 1.

distributions. In general, those poeciliid species whose population abundances have been described are usually dominant species in their habitats, with population densities varying between 8 and 44 individuals per $\mathrm{m}^{2}$ (Meffe and Snelson 1989, Jordan et al. 1998, Reznick et al. 2001, Alexandre et al. 2010). More interesting is the fact that the number of individuals can vary drastically among populations, and factors such as food and shelter availability, or the presence or absence of predators and competitors, have been proposed as the main causes of this spatial variation (Chapman et al. 1991, Belk and Lydeard 1994, Reznick et al. 2001, Richardson et al. 2006). Nevertheless, a complete picture of the fundamental demographic parameters of this fish family requires the study of species with more restricted geographic distributions.

Poeciliopsis baenschi is one example of a viviparous fish species inhabiting only a few river drainages in a neotropical dry forest. This species is endemic to streams and rivers in the states of Jalisco and Colima in western Mexico (Miller et al. 2005). Like other species in the family Poeciliidae, males internally inseminate females using a modified anal fin (gonopodium), and females give birth to free-swimming young. This species exhibits marked sexual dimorphism in size, and adult females are larger than adult males: 24.4 and $21.3 \mathrm{~mm}$ mean standard length (SL), respectively. However, both sexes appear to mature at similar sizes: 18.6 and $19.5 \mathrm{~mm}$ SL for females and males, respectively. Females exhibit superfetation, which is the ability to simultaneously carry multiple broods of embryos at different stages of development (Turner 1937, Scott and Johnson 2010). To date, nothing is known about the behavior, physiology, feeding habits, or population dynamics of this viviparous fish (Miller et al. 2005).

In this study, we estimated population abundance and sex ratio for 6 different populations of P. baenschi (Fig. 1). The selected populations span most of the geographic distribution of the species. We selected P. baenschi as our focal species for 2 main reasons. First, its populations occur only in a restricted area of the Pacific Slope in western Mexico (Miller et al. 2005). In this region, several factors such as water pollution, urban development, and extensive agriculture are negatively affecting the main fluvial systems and, in consequence, are threatening the native species (Ceballos and García 1995, Castillo et al. 2009, Masek et al. 2011). Second, no study has been conducted on the demographic parameters of this species, and thus, no quantitative information is available to guide future conservation actions. 
Essentially, we aimed to answer this question: what is the influence of different rivers on the population abundance and sex ratio of $P$. baenschi? Given that the 6 studied rivers differ markedly in key environmental conditions, such as the presence or absence of potential predators or competitors, we expected to find marked differences among populations in both abundance and sex ratio. Our results represent a significant contribution to the knowledge of a freshwater fish species endemic to the tropical dry forest of western Mexico and a reference for future similar studies quantifying basic demographic traits of neotropical fauna.

\section{Methods}

\section{Study Sites}

For this study we selected 6 different localities that represent independent fluvial systems with no inland connection among them (Fig. 1). Thus, our study localities represent different populations of $P$. baenschi. These sites span a large proportion of the geographic range in which P. baenschi can be found (Miller et al. 2005). In fact, we selected these sampling sites because they correspond to most of the river drainages which this species inhabits. The only exception was a small stream located $50 \mathrm{~km}$ south of Puerto Vallarta city, which is separated from our closest sampling site by about $110 \mathrm{~km}$. For logistic reasons, we could not sample at this relatively distant location. Thus, our study sites span most of the types of rivers and streams in which $P$. baenschi occurs.

The sampling rivers differ markedly in certain environmental variables (Table 1). First, the particular freshwater fish species with which $P$. baenschi coexist vary among sites (Miller et al. 2005, Álvarez-Romero et al. 2008). Interestingly, in 4 of the 6 sampling localities, members of the family Cichlidae are present, and these fishes might prey on P. baenschi (Reznick et al. 1996, Johnson and Belk 2001). Second, 2 sampling localities were small streams, and the other 4 were relatively large rivers. This dichotomous classification of our sites as either stream or river depended on the width of the riverbed. We arbitrarily defined rivers as waterways wider than $5 \mathrm{~m}$ and streams as those narrower than $5 \mathrm{~m}$. Third, our sampling localities also differed in the presence (or absence) of conspicuous signs of human- induced disturbance, such as close proximity to rural human settlements and the occurrence of waste materials in the riverbed. Based on these criteria, we classified the sites as either disturbed or pristine. Table 1 shows a description of the study sites, as well as sample sizes (i.e., number of captured and marked fish per population).

\section{Fish Sampling}

To estimate population abundance and sex ratio we conducted capture-mark-recapture experiments during the dry seasons of 2009 and 2010. We visited the sampling sites once a week during a 5 -week period. The only exception was population 4 that was visited weekly during a 4 -week period. Sites 1-4 were sampled during October-November 2009. Sites 5 and 6 were sampled during October-November 2010. At each population we selected one focal pool, and on each visit we attempted to collect all fish in the pool by repeated seining. For this purpose, we used handheld seine nets $(1.3 \mathrm{~m}$ high $\times 5 \mathrm{~m}$ long, 8-mm mesh size). Upon first capture, each fish was anesthetized using MS222 , measured, and marked individually with visible implant elastomer (VIE) tags (Northwest Marine Technology, Inc.) injected in the caudal peduncle. Also on each first capture, we determined the sex of each individual by the presence or absence of the male gonopodium. On subsequent recaptures the individual mark was identified and individuals were measured again. On every visit we caught both previously marked and unmarked fish (except for the first occasion in which only unmarked individuals were caught; Table 2). All the individuals caught without a mark were individually marked as well. We only marked and followed fish larger than $15 \mathrm{~mm} \mathrm{SL}$, because smaller individuals were seriously affected by the anesthetic and the injection of VIE tags. Our weekly sampling procedure allowed us to obtain individualized recapture (encounter) histories for each marked fish throughout a 5 -week period (4-week period in the case of site 4).

\section{Data Analyses}

To estimate population abundance we used both our catch data and estimates of capture probability. We could not consider the number of individuals caught per population or sampling occasion as direct estimates of population 


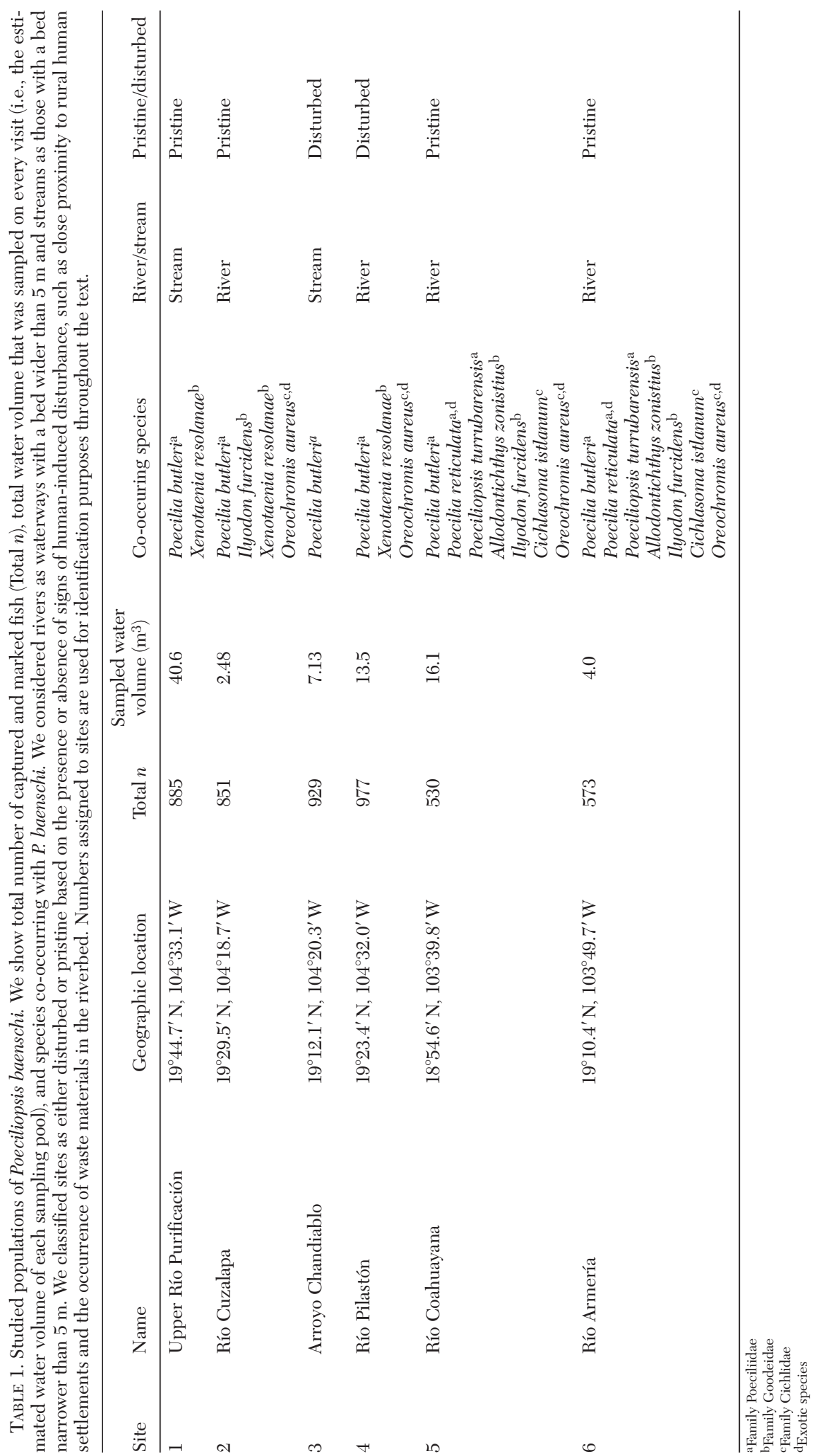




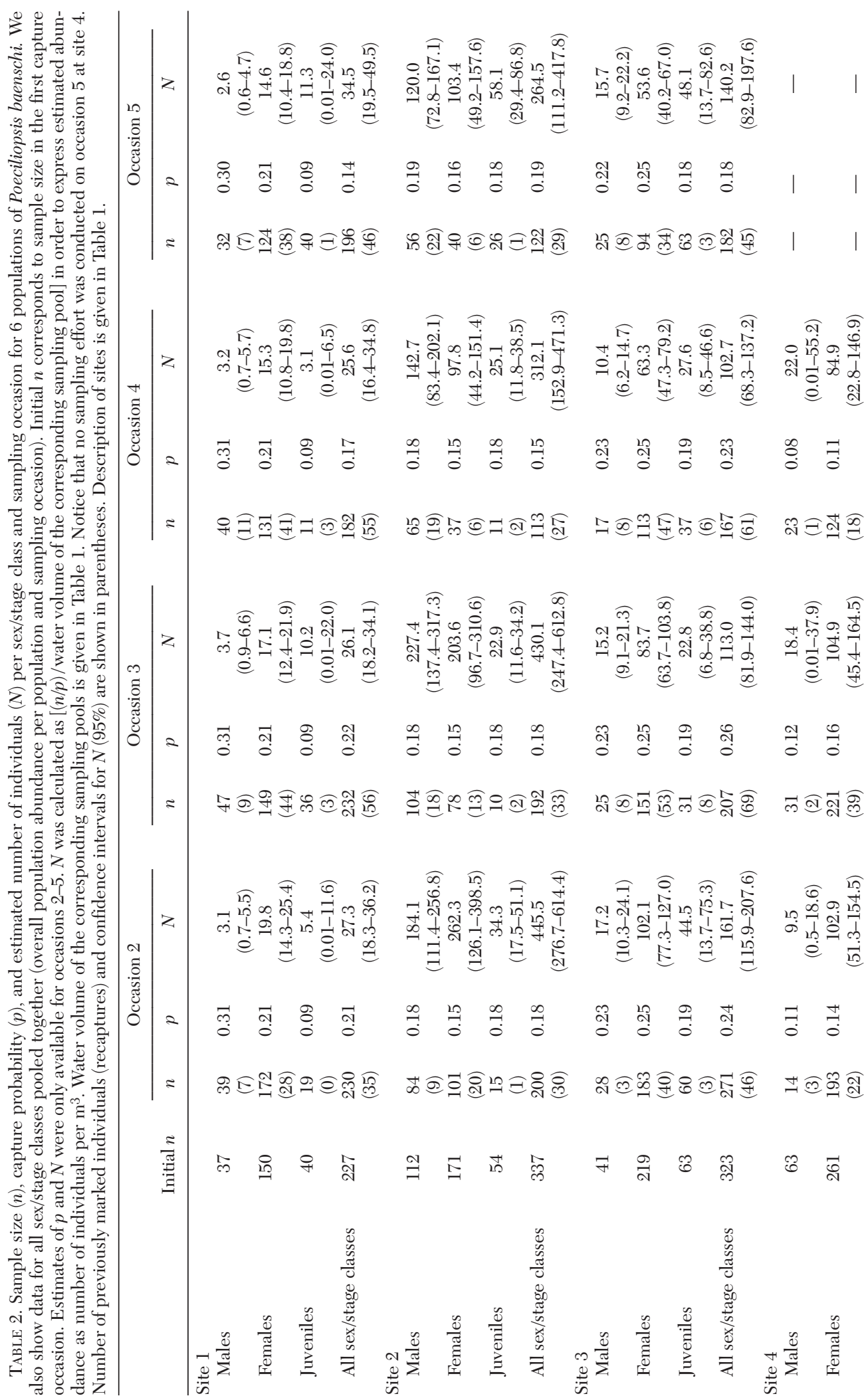




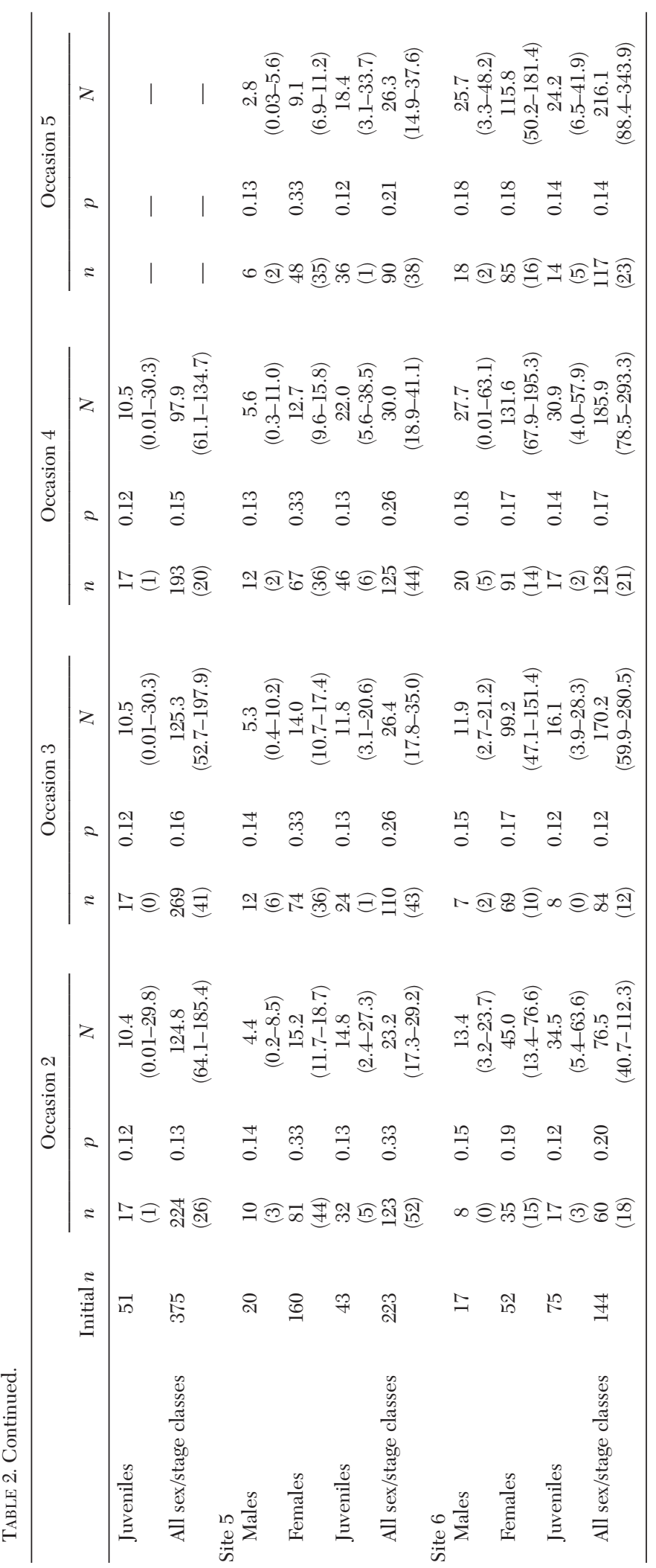


abundance because we might have missed a large number of individuals actually present during our sampling events. Therefore, we began by estimating capture probability $(p)$ per sex, stage class, and sampling occasion for each study site. We structured the populations into 3 groups or sex/stage classes: (1) adult males: fishes with gonopodium present and larger than $19.5 \mathrm{~mm} \mathrm{SL}$; (2) adult females: fishes with gonopodium absent and larger than $18.6 \mathrm{~mm} \mathrm{SL}$; and (3) juveniles: fishes larger than $15 \mathrm{~mm}$ SL and smaller than 19.5 and 18.6 $\mathrm{mm}$ SL for males and females, respectively (Scott and Johnson 2010). As sex is not evident in small fishes $(<18.6 \mathrm{~mm} \mathrm{SL})$ because of incomplete development of the gonopodium, we did not distinguish males from females in the juvenile class.

We used maximum likelihood procedures implemented in the program MARK to estimate $p$ for each sex/stage class, sampling occasion, and population (White and Burnham 1999). MARK finds the values of $p$ that maximize the likelihood of obtaining the observed encounter histories. Additionally, this computer program uses likelihood functions to calculate standard errors for $p$ (Lebreton et al. 1992). Estimates of $p$ were only available for occasions $2-5$ given that there were no previously marked animals during the first sampling occasion.

Using estimates of $p$, we calculated the number of individuals present per sex/stage class, sampling occasion, and population $\left(N_{i}\right)$ as follows:

$$
N_{i}=n_{i} / p_{i},
$$

where $n$ represents the number of individuals caught (sample size) and $i$ represents any combination of sex/stage class, sampling occasion, and population. Notice that this formula accounts for the specific probability of capturing animals when estimating the actual number of individuals present. Estimates of $N$ could only be calculated for occasions $2-5$ because no estimate of $p$ was available for occasion one. Standard errors (SE) for $N_{i}$ were calculated as

$$
\mathrm{SE}\left(N_{i}\right)=\left(n_{i} \times \mathrm{SE}\left[p_{i}\right]\right) / p_{i}{ }^{2} .
$$

Confidence intervals (95\%) were constructed as $1.96 \times \mathrm{SE}\left(N_{i}\right)$, assuming a normal distribution of $N_{i}$. This procedure for estimating popu- lation abundance (along with SE) has been implemented in previous studies on demographic parameters of animal populations (e.g., Wood et al. 1998, Armstrong et al. 2005, ZúñigaVega 2011). For each population, we reported weekly estimates for number of individuals per sex/stage class $\left(N_{i} \pm \mathrm{SE}\right.$ and $95 \%$ confidence intervals).

In addition, we calculated overall population abundance (juveniles, males, and females together) per sampling occasion as the ratio between the total number of captured fish per occasion (total $n$ ) and the estimated occasionspecific values of $p$ for all the individuals pooled into a single group. Standard errors for these estimates of overall population abundance were also calculated as explained above. Sex ratio was simply calculated as the ratio between the estimated number of adult males and females present at each population. For comparative purposes, all estimates are given as per unit water volume (individuals $\cdot \mathrm{m}^{-3}$ ), because the volume of the selected sampling pool was different among study sites (Table 1).

\section{RESUlTS}

The estimated number of individuals in each sex/stage class per sampling occasion and per unit water volume $\left(\mathrm{m}^{3}\right)$ was widely variable among populations (Fig. 2). The estimated number of males per $\mathrm{m}^{3}( \pm \mathrm{SE})$ was as low as $2.6 \pm 1.0$ in site 1 and as high as 227.4 \pm 45.9 in site 2 . The estimated number of females per $\mathrm{m}^{3}$ was as low as $9.1 \pm 1.1$ in site 5 and as high as $262.3 \pm 69.5$ in site 2 . The estimated number of juveniles per $\mathrm{m}^{3}$ was as low as $3.1 \pm 1.7$ in site 1 and as high as $58.1 \pm$ 14.6 in site 2 . Table 2 shows all estimates for number of individuals per sex/stage class, sampling occasion, and population (expressed per $\mathrm{m}^{3} \pm 95 \%$ confidence intervals) as well as sample sizes $\left(n_{i}\right)$ and capture probabilities $\left(p_{i}\right)$.

The calculated overall population abundance per sampling occasion was also spatially variable. Site 2 exhibited the highest population abundances of $P$. baenschi (between 312.1 and 445.5 individuals $\cdot \mathrm{m}^{-3}$; Fig. 2, Table 2). The lowest population abundances occurred at site 5 (between 23.2 and 30.0 individuals. $\mathrm{m}^{-3}$; Fig. 2, Table 2). Overall population abundances (averaged across sampling occasions) were as follows: site 1: $25.5 \pm 3.1$; site 2: $363.2 \pm$ 60.5 ; site 3: $119.3 \pm 12.8$; site $4: 119.3 \pm 28.6$; 

$\triangle$ Males
Females
Juveniles
Total population size
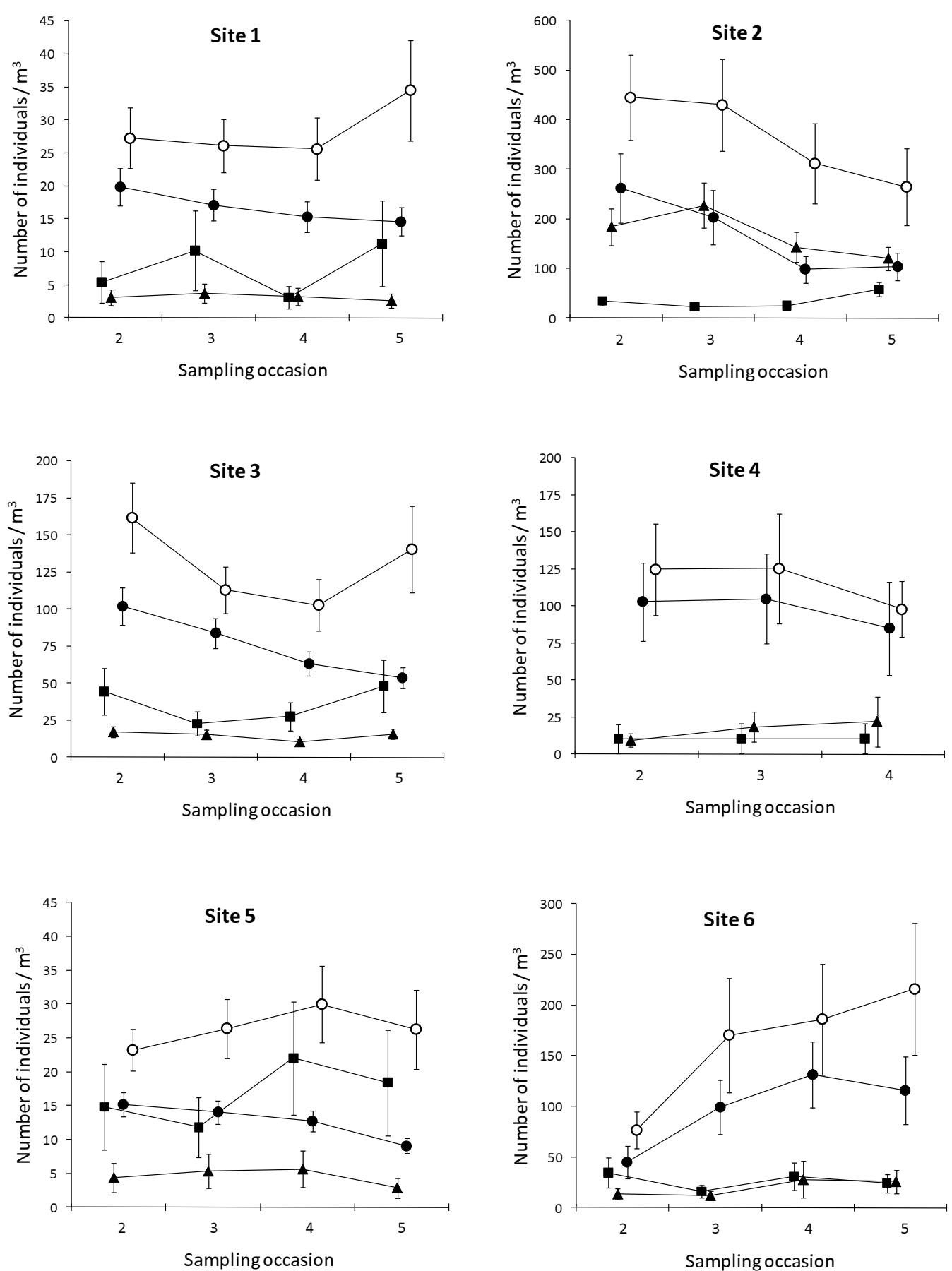

Fig. 2. Estimated number of individuals per sex/stage class, population, and sampling occasion. Estimates are shown per unit water volume $\left(\mathrm{m}^{3}\right)$. For visualization purposes, the scales of the $y$-axes differ depending on the abundance of individuals per population. Estimates were available beginning with sampling occasion 2 . Site 4 was visited only in 4 occasions instead of 5 . Vertical bars denote one standard error around the mean. 
site $5: 23.8 \pm 2.7$; and site $6: 148.1 \pm 29.6$ individuals $\cdot \mathrm{m}^{-3}$.

A recurring pattern (present in 5 of our 6 study sites) that arose in the population estimates was that sex ratio was markedly biased toward females (Fig. 2). The largest difference in abundance between sexes occurred at site 6 . There the maximum estimate for number of females per $\mathrm{m}^{3}$ was $131.6 \pm 32.5$, whereas the minimum estimate for number of males per $\mathrm{m}^{3}$ was only $11.9 \pm 4.7$ (Table 2 ); this represents a sex ratio (females: males) equal to 11.1:1. In fact, even juveniles were more abundant than adult males in sites 3 and 5 (Fig. 2). The average sex ratios (females: males) across sampling occasions for study sites $1,3,4,5$, and 6 were $6.0: 1,4.9: 1,3.1: 1,2.6: 1$, and $4.4: 1$, respectively. The only exception from this female-biased sex ratio was site 2 , in which sex ratio was approximately 1:1 (Fig. 2, Table 2 ).

\section{Discussion}

Population Abundance

We found remarkable spatial variation in population abundance of $P$. baenschi. Given the contrasting ecological conditions observed in the 6 studied rivers, this result is not surprising. However, the site-specific environmental variables that we recorded cannot account for the differences among populations in the abundance of $P$. baenschi. This species can be either abundant or relatively rare in the presence of the same array of potential predators and competitors. For instance, in sites 5 and $6, P$. baenschi coexists with the same members of the families Poeciliidae, Goodeidae (potential competitors), and Cichlidae (potential predators; Table 1). However, in site $5, P$. baenschi is relatively rare, whereas in site 6 it is considerably abundant (Fig. 2). The size of the riverbed could not determine the abundance of $P$. baenschi either. These fish can be abundant in relatively large rivers, such as that sampled in site 2, as well as in small streams, such as that sampled in site 3. In contrast, $P$. baenschi abundance can be markedly low in both rivers (e.g., site 5) and streams (e.g., site 1). The same was true for humaninduced disturbance; P. baenschi was abundant in both pristine and disturbed river drainages, such as sites 2 and 4, respectively. Certainly, these and other ecological factors, such as food availability or the presence of parasites, must be measured with more precision in order to understand the factors causing the observed variation among populations in the abundance of P. baenschi (Belk and Lydeard 1994, Garcia et al. 2004, Richardson et al. 2006, Alexandre et al. 2010).

Careful attention should be paid to those sites at which the abundance of $P$. baenschi is remarkably low (i.e., sites 1 and 5). This is the first study measuring the number of individuals per $\mathrm{m}^{3}$ for this species, and thus, we do not know whether the observed abundances were higher in the past. If so, 2 hypotheses that deserve further research arise. The first is that population size at these localities is decreasing and that there is now certain risk of local extinction. If this were the case, we would recommend the implementation of conservationbased research programs at these 2 localities. In fact, other poeciliids are now considered locally extinct, presumably as a result of recent human-induced disturbance (e.g., Priapella bonita and Xiphophorus couchianus; ContrerasBalderas et al. 2003). The second hypothesis is that there is year-to-year natural variability in the population abundance of this species. Previous studies have documented temporal variability in demographic parameters of poeciliid fishes (e.g., Gómez-Márquez et al. 2008, Súarez et al. 2009). We could have sampled sites 1 and 5 during years in which environmental conditions promoted low abundance of $P$. baenschi. In fact, we recognize that our markrecapture experiments were conducted in different years (2009 for sites 1-4 and 2010 for sites 5 and 6). Thus, an important assumption underlying our results and conclusions is that interannual variation in the demographic characteristics of $P$. baenschi is minimal in comparison with variation among populations. An alternative hypothesis that also remains to be tested is that the abundance of $P$. baenschi is naturally low at sites 1 and 5 .

\section{Sex Ratio}

Our most remarkable finding was the sex ratio of $P$. baenschi. In most of our study sites, females were markedly more abundant than males. Sex ratio can be as biased as 11 females per male. Biased sex ratios have been documented previously in freshwater fishes, including poeciliids (Hughes 1985a, 1985b, Zulian et al. 1995, Cognato and Fialho 2006, Andrade et al. 2008). In contrast, in the population where 
we observed the highest abundance (site 2), sex ratio was 1:1. This interesting difference may have important consequences in terms of male-male competition, sexual selection mechanisms, and phenotypic divergence in this site with respect to all other populations (MacíasGarcia 1994, Smith 2007). Nevertheless, the observed differences among populations in sex ratio can also result from seasonal or interannual variability in the number of males and females present, such as has been reported for other poeciliid fishes (Gómez-Márquez et al. 2008, Súarez et al. 2009).

What causes female-biased sex ratios? Biased sex ratios are the result of processes occurring during fertilization (e.g., sex-determining chromosomes), during embryonic development and birth, during the juvenile stage, or after sexual maturity (McKellar et al. 2009). Neither sex-linked inheritance nor sex chromosomes have been found in Poeciliopsis species (Sullivan and Schultz 1986, Schultheis et al. 2009). Thus, any process during fertilization can be discarded for P. baenschi. Among the factors that may affect the proportion of sexes during embryonic development, temperature exerts a significant effect in poeciliids, with low water temperature resulting in more females and high water temperature resulting in more males (Ospina-Álvarez and Piferrer 2008).

If the proportion of sexes is 1:1 at birth in $P$. baenschi, then males and females must experience distinct selective pressures before and/or after maturity. This differential selection can result in biased adult sex ratios. Among the factors that can differentially affect males and females are sex-specific migration patterns, distinct mortality rates associated with differential susceptibility to predators, intersexual differences in resource acquisition under lowresource levels, inter- or intrasexual aggression, and sex-specific reproductive costs (Girondot and Pieau 1993, Ghalambor et al. 2004, McKellar et al. 2009). These and other factors might interact to produce the markedly femalebiased sex ratios observed in P. baenschi. Their potential effects represent a fertile field for future research.

\section{Concluding Remarks}

We have provided basic demographic information for several populations of the livebearing fish Poeciliopsis baenschi. We can high- light 2 main findings. First, population abundance varies widely among populations. Second, sex ratio in most of the studied sites is noteworthy: females are considerably more abundant than males. The steps to follow should be to calculate population growth rates and to examine temporal (e.g., seasonal) variation in the observed demographic parameters. In fact, we recognize that our data are restricted to the dry season, whereas both abundance and sex ratio can vary markedly throughout the year (Gómez-Márquez et al. 2008, Súarez et al. 2009).

\section{ACKNOWLEDGMENTS}

We thank Josh Rasmussen for helpful comments on the manuscript. Field assistance was provided by Pedro Mendoza-Hernández, Claudia Molina-Zuluaga, Claudia OliveraTlahuel, Jonathan Maceda-Cruz, and Alejandra Martínez-Blancas. Jaime Zúñiga-Gutiérrez provided logistic support. Funding for this project was provided by the Dirección General de Asuntos del Personal Académico-Universidad Nacional Autónoma de México through the project PAPIIT IN206309-3. Fieldwork was conducted under permit no. FAUT-0240 issued by the Secretaría de Medio Ambiente y Recursos Naturales-México.

\section{Literature Cited}

Achard, F., H.D. Eva, H.J. Stibig, P. Mayaux, J. Gallego, T. Richards, and J.P. Malingreau. 2002. Determination of deforestation rates of the world's humid tropical forests. Science 297:999-1002.

Alexandre, C.V., K.E. Esteves, And M.A.M.D.E. MELLO. 2010. Analysis of fish communities along a rural-urban gradient in a neotropical stream (Piracicaba River Basin, São Paulo, Brazil). Hydrobiologia 641:97-114.

Álvarez-Romero, J.G., R.A. Medellín, A. Oliveras de ITA, H. GÓmEZ DE Silva, AND O. SÁnchez. 2008. Animales exóticos en México: una amenaza para la biodiversidad. Comisión Nacional para el Conocimiento y Uso de la Biodiversidad, Universidad Nacional Autónoma de México, Secretaria de Medio Ambiente y Recursos Naturales, Mexico City, Mexico.

Andrade, V.X.L., F.F.S. Campos, F. Langeani, and E. Romagosa. 2008. Reproductive dynamics of the main species of fish in the municipal reservoir of São José Do Rio Preto. Boletim do Instituto de Pesca 34:365-373.

Arce-Uribe, E. 2006. Abundancia y distribución poblacional de Poblana alchichica (Pisces: Atherinopsidae) charal endémico del Lago Alchichica, Puebla. Master's thesis, Universidad Nacional Autónoma de México, Mexico City, Mexico. 
Armstrong, D.P., R.S. Davidson, J.K. Perrott, J. RoyGARD, AND L. Buchanan. 2005. Density-dependent population growth in a reintroduced population of North Island saddlebacks. Journal of Animal Ecology 74:160-170.

BelK, M.C., AND C. LydeARD. 1994. Effect of Gambusia holbrooki on a similar-sized, syntopic poeciliid, Heterandria formosa: competitor or predator? Copeia 1994:296-302.

Bronikowski, A.M., M.E. Clark, F.H. Rodd, and D.N. REZnICK. 2002. Population-dynamic consequences of predator-induced life history variation in the guppy (Poecilia reticulata). Ecology 83:2194-2204.

Canto-Maza, W.G., and M.E. Vega-Cendejas. 2007. Distribución, abundancia y preferencias alimenticias del pez sapo Opsanus phobetron (Batrachoididae) en la laguna costera de Chelem, Yucatán, México. Revista de Biología Tropical 55:979-988.

Castillo, A., C. Godínez, N. Schroeder, C. Galicia, A. Pujadas-Bote, And L. Hernández. 2009. El bosque tropical seco en riesgo: conflictos entre uso agropecuario, desarrollo turístico y provisión de servicios ecosistémicos en la costa de Jalisco, México. Interciencia 34:844-850.

Caswell, H. 2000. Prospective and retrospective perturbation analyses: their roles in conservation biology. Ecology 81:619-627.

2001. Matrix population models. Construction, analysis, and interpretation. 2nd edition. Sinauer Associates, Sunderland, MA.

Ceballos, G., and A. García. 1995. Conserving neotropical biodiversity: the role of dry forests in western Mexico. Conservation Biology 9:1349-1353.

Chapman, L.J., D.L. Kramer, and C.A. Chapman. 1991. Population dynamics of the fish Poecilia gillii (Poeciliidae) in pools of an intermittent tropical stream. Journal of Animal Ecology 60:441-442.

Cognato, D.D., and C.B. Fialho. 2006. Reproductive biology of a population of Gymnotus aff. carapo (Teleostei: Gymnotidae) from southern Brazil. Neotropical Ichthyology 4:339-348.

Contreras-Balderas, S., P. Almada-Villela, M.L. Lozano-Vilano, and M.E. García-Ramírez. 2003. Freshwater fish at risk or extinct in México. A checklist and review. Reviews in Fish Biology and Fisheries 12:241-251.

DUNCAN, J.R., AND J.L. LOCKWOOD. 2001. Extinction in a field of bullets: a search for causes in the decline of the world's freshwater fishes. Biological Conservation 102:97-105.

Evans, J.P., A. Pilastro, and I. Schlupp, EDitors. 2011 Ecology and evolution of poeciliid fishes. University of Chicago Press, Chicago, IL.

Garcia, A.M., J.P. Vieira, K.O. Winemiller, and M.B. RASEIRA. 2004. Reproductive cycle and spatiotemporal variation in abundance of the one-sided livebearer Jenynsia multidentata, in Patos Lagoon, Brazil. Hydrobiologia 515:39-48.

Ghalambor, C.K., D.N. Reznick, and J.A. Walker. 2004. Constraints on adaptive evolution: the functional trade-off between reproduction and fast-start swimming performance in the Trinidadian guppy (Poecilia reticulata). American Naturalist 164:38-50.

Girondot, M., and C. Pieau. 1993. Effects of sexual differences of age at maturity and survival on population sex ratio. Evolutionary Ecology 7:645-650.
Gómez-Márquez, J.L., B. Peña-Mendoza, I.H. SalgadoUgarte, A.K. Sánchez-Herrera, and L. SastréBAEz. 2008. Reproduction of the fish Poeciliopsis gracilis (Cyprinodontiformes: Poeciliidae) in Coatetelco, a tropical shallow lake in Mexico. Revista de Biología Tropical 56:1801-1812.

High, B., K.A. Meyer, D.J. Schill, and E.R.J. Mamer. 2008. Distribution, abundance, and population trends of Bull Trout in Idaho. North American Journal of Fisheries Management 28:1687-1701.

Hughes, A.L. 1985a. Seasonal changes in fecundity and size at first reproduction in an Indiana population of the mosquitofish Gambusia affinis. American Midland Naturalist 114:30-36.

1985b. Seasonal trends in body size of adult male mosquitofish, Gambusia affinis, with evidence for their social control. Environmental Biology of Fishes $14: 251-258$.

Johnson, J.B., AND J.C. BAGLEy. 2011. Ecological drivers of life-history divergence in poeciliid fishes. Pages 38-49 in J.P. Evans, A. Pilastro, and I. Schlupp, editors, Ecology and evolution of poeciliid fishes. University of Chicago Press, Chicago, IL.

Johnson, J.B., AND M.C. BELK. 2001. Predation environment predicts divergent life-history phenotypes among populations of the livebearing fish Brachyrhaphis rhabdophora. Oecologia 126:142-149.

Johnson, J.B., And J.J. ZúñIgA-VEGA. 2009. Differential mortality drives life-history evolution and population dynamics in the fish Brachyrhaphis rhabdophora. Ecology 90:2243-2252.

Jordan, F., K.J. Babbitt, And C.C. McIvor. 1998. Seasonal variation in habitat use by marsh fishes. Ecology of Freshwater Fish 7:159-166.

Killgore, K.J., J.J. Hoover, S.G. George, B.R. Lewis, C.E. Murphy, and W.E. Lancaster. 2007. Distribution, relative abundance and movements of pallid sturgeon in the free-flowing Mississippi River. Journal of Applied Ichthyology 23:476-483.

Lebreton, J.D., K.P. Burnham, J. Clobert, and D.R. ANDERSON. 1992. Modeling survival and testing biological hypotheses using marked animals: a unified approach with case studies. Ecological Monographs 62:67-118.

MaCías-GaRCia, C. 1994. Social behavior and operational sex ratios in the viviparous fish Girardinichthys multiradiatus. Copeia 1994:919-925.

Masek, G.J., W.B. Cohen, D. Leckie, M.A. Wulder, R. Vargas, B. de Jong, S. Healey, B. Law, R. Birdsey, R.A. Houghton, D. Mildrexler, S. Goward, and W.B. SMith. 2011. Recent rates of forest harvest and conversion in North America. Journal of Geophysical Research Atmospheres 116:G00K03.

McKellar, A.E., M.M. Turcotte, and A.P. Hendry. 2009. Environmental factors influencing adult sex ratio in Trinidadian guppies. Oecologia 159:735-745.

MeFFE, G.K., AND FF SNELSON JR., EDITORS, 1989. Ecology and evolution of livebearing fishes (Poeciliidae). Prentice-Hall, Englewood Cliffs, NJ.

Miguel, A. 1991. Environmental pollution research in South America. Environmental Science \& Technology 25:590-594.

Miller, R.R., W.L. Minckley, and S.M. NorRis. 2005. Freshwater fishes of México. University of Chicago Press, Chicago, IL.

Ospina-Álvarez, N., AND F. Piferrer. 2008. Temperature-dependent sex determination in fish revisited: 
prevalence, a single sex ratio response pattern, and possible effects of climate change. PLoS ONE 3: e2837.

Ramos-Santiago, E., J.M. Ramírez-Gutiérrez, R. MenDOZA-Rodríguez, AND M. TAPIA-García. 2006. Reproducción, distribución y abundancia del pez Pseudupeneus grandisquamis (Perciformes: Mullidae), en el Golfo de Tehuantepec, México. Revista de Biología Tropical 54:1103-1112.

Reznick, D.N., M.J. Butler IV, ANd F.H. Rodd. 2001. Life-history evolution in guppies. VII. The comparative ecology of high- and low-predation environments. American Naturalist 157:126-140.

Reznick, D.N., M.J. Butler IV, F.H. RodD, and P. Ross. 1996. Life-history evolution in guppies (Poecilia reticulata) 6. Differential mortality as a mechanism for natural selection. Evolution 50:1651-1660.

Richardson, J.M.L., M.S. Gunzburger, and J. Travis. 2006. Variation in predation pressure as a mechanism underlying differences in numerical abundance between populations of the poeciliid fish Heterandria formosa. Oecologia 147:596-605.

Schultheis, C., A. Böhne, M. Schartl, J.N. VolfF, and D. Galiana-Arnoux. 2009. Sex determination diversity and sex chromosome evolution in poeciliid fish. Sexual Development 3:68-77.

ScotT, L.E., AND J.B. Johnson. 2010. Does sympatry environments predict life history and morphological diversification in the Mexican livebearing fish Poeciliopsis baenschi? Biological Journal of the Linnean Society 100:608-618.

SмiтH, C.C. 2005. Sexual conflict and density dependence in the western mosquitofish, Gambusia affinis (Poeciliidae). Master's thesis, University of Kentucky, Lexington, KY.

2007. Independent effects of male and female density on sexual harassment, female fitness, and male competition for mates in western mosquitofish
Gambusia affinis. Behavioral Ecology and Sociobiology 61:1349-1358.

SÚareZ, Y.R., J.P. DA Silva, L.P. VASCONCElos, AND W.F. ANTONIALLI-JÚNioR. 2009. Ecology of Phallotorynus pankalos (Cyprinodontiformes: Poeciliidae) in a firstorder stream of the upper Paraná Basin. Neotropical Ichthyology 7:49-54

Sullivan, J.A., AND R.J. Schultz. 1986. Genetic and environmental basis of variable sex ratios in laboratory strains of Poeciliopsis lucida. Evolution 40:152-158.

Turner, C.L. 1937. Reproductive cycles and superfetation in poeciliid fishes. Biological Bulletin 72:145-164.

White, G.C., And K.P. Burnham. 1999. Program MARK: survival estimation from populations of marked animals. Bird Study 46:S120-S139.

Williams, B.K., J.D. Nichols, and M.J. Conroy. 2002. Analysis and management of animal populations. Academic Press, San Diego, CA.

Wood, K.V., J.D. Nichols, H.F. Percival, and J.E. Hines. 1998. Size-sex variation in survival rates and abundance of pig frogs, Rana grylio, in northern Florida wetlands. Journal of Herpetology 32:527-535.

Young, J.A.M., J.R. Marentette, C. Gross, J.I. McDonald, A. Verma, S.E. Marsh-Rollo, P.D.M. MacDonald, D.J.D. Earn, and S. BaLshine. 2010. Demography and substrate affinity of the round goby (Neogobius melanostomus) in Hamilton Harbour. Journal of Great Lakes Research 36:115-122.

Zulian, E., A. BisaZZA, AND G. Marin. 1995. Variations in male body size in natural populations of Gambusia holbrooki. Ethology Ecology \& Evolution 7:1-10.

ZÚÑIGA-VEGA, J.J. 2011. Estimating potential reproductive costs in the survival of a xenosaurid lizard. Herpetological Journal 21:117-129.

Received 29 February 2012 Accepted 4 May 2012 